\title{
Efektifitas Kerja Peserta Magang Dalam Meningkatkan Minat Berwirausaha
}

\author{
Anisa Ikhsan 1), Roy Hasiru 2), Muchtar Ahmad ${ }^{3)}$ \\ 1)Mahasiswa Fakultas Ekonomi, Universitas Negeri Gorontalo \\ 2),3)Dosen Fakultas Ekonomi, Universitas Negeri Gorontalo \\ nisaikhsan56@gmail.com
}

\begin{abstract}
This research aimed to reveal the "work effectiveness of vocational students' internships in increasing entrepreneurial interest in the Pia Putra Kusuma Gorontalo Company", a case study of the on-the-job-training students at Putra Kusuma LKP. This study employed a qualitative descriptive method. The data collection techniques used in this study were observations, interviews, and documentation. It is revealed that: 1 . The intern greatly aided the company in terms of office operation. 2 . The interns were considered to be extremely helpful in the process of operational activities, starting from the production to the marketing stage, 3. The entrepreneurial interests of interns at LKP Pia Putra Kusuma are significantly diverse. It was shown that the interest in entrepreneurship manifested in a number of the interns.
\end{abstract}

Keyword: Work of Internship Participants, Interest in Entrepreneurship

Pendahuluan

Pembangunan sumber daya manusia perlu dilaksanakan secara menyeluruh, terarah, dan terpadu di berbagai bidang, terutama yang mencakup bidang pendidikan, latihan, serta penyediaan lapangan kerja. Program pengembangan sumber daya manusia pada dasarnya diarahkan agar manusia mampu beradaptasi dengan lingkungan serta mampu aktif mengeksplorasi lingkungan.

Pengembangan kemampuan intelektual, keterampilan dan kreativitas sangat diperlukan oleh setiap pelaku wirausaha, sehingga mereka mampu mandiri dan selalu berupaya meningkatkan etos kerja yang selanjutnya mereka dapat memperoleh kesempatan kerja atau membuka usaha sendiri(berwirausaha).
(Yudi Yuniarto, 2014:8)

Wirausaha merupakan salah satu pendukung yang menentukan maju mundurnya perekonomian, karena bidang wirausaha mempunyai kebebasan untuk berkarya dan mandiri.

Wirausaha mampu menciptakan lapangan kerja atau menyerap tenaga kerja. Ricky W. Griffin mengemukakan bahwa kewirausahaan (entrepreneurship) adalah pemikiran untuk pengelolaan usaha kecil. Pernyataan Griffin yang mengemukakan bahwa kewirausahaan terkait dengan pemikiran untuk pengelolaan usaha kecil dapat dimengerti karena kebanyakan wirausaha yang sukses memang memulai usahanya dari usaha kecil. Dalam perkembangannya konsep kewirausahaan berlaku juga untuk 
pegelolaan usaha besar. Karena disadari ataupun tidak, dunia pendidikan pun sudah sejak lama menanamkan nilainilai kewirausahaan dengan mengembangkan UMKM (Usaha Mikro Kecil dan Menengah) melalui program yang terkait dengan masyarakat dan UMKM.

Pilihan menjadi seorang pengusaha merupakan pilihan yang tepat saat ini sebab dengan berwirausaha berarti menyediakan lapangan kerja bagi diri sendiri dan tidak perlu bergantung kepada orang lain. Apabila usahanya semakin maju, para pengusaha mampu membuka lapangan kerja bagi orang lain. Saat ini para penganggur tak hanya berstatus lulusan SD (Sekolah Dasar) sampai SMA (Sekolah Menengah Atas) saja, tetapi juga banyak sarjana yang menganggur. Salah satu cara untuk mengurangi pengangguran tersebut adalah mempersiapkan manusia terdidik yang mampu menyediakan lapangan kerja bagi diri sendiri, bahkan menciptakan lapangan kerja bagi orang lain. Dengan berbekal sebagai manusia profesional, maka para angkatan kerja dapat berkembang lebih lanjut, menciptakan lapangan kerja untuk dirinya sendiri dan bahkan mampu menciptakan lapangan kerja bagi orang lain ( Suryaman 2006:54).

Sebagai langkah awal untuk memulai sebuah usaha atau berwirausaha adalah adanya minat pada diri calon wirausahawan. Berdasarkan latar belakang pendidikannya, lulusan SMK diperkirakan memiliki minat untuk berwirausaha, hal ini disebabkan karena mereka memiliki kemampuan penalaran dan keterampilan yang memadai. Dalam berwirausaha siswa SMK sangat berbakat dikarenakan mereka mempunyai pengalaman dalam praktek kerja lapangan, praktek kerja lapangan membuat wawasan siswa SMK menjadi luas dalam berwirausaha salah satunya kegiatan yang terjadi ditempat pelaksanaan yaitu: produksi,pemasaran, dan penjualan. Kegiatan penjualan sering dilakukan oleh siswa PKL karena dalam penjualan siswa PKL dapat mengetahui wawasan dalam berwirausaha. Data yang sudah di peroleh siswa magang pada perusahaan PIA PUTRA KUSUMA dari tahun 2018,2019 dan 2020 yakni :

Tabel 1 Angkatan

\begin{tabular}{|c|c|c|c|}
\hline $\begin{array}{c}\text { Uraian } \\
\text { Angkatan }\end{array}$ & $\begin{array}{l}\text { Jumlah } \\
\text { Peserta }\end{array}$ & Jurusan & $\begin{array}{c}\text { Asal } \\
\text { Sekolah }\end{array}$ \\
\hline $\begin{array}{c}25 \\
\text { Agustus- } \\
\text { Oktober } \\
2018\end{array}$ & $\begin{array}{c}8 \\
\text { Peserta }\end{array}$ & APHP & $\begin{array}{c}\text { SMKN } 4 \\
\text { Gorut } \\
\text { SMKN } 2 \\
\text { Limboto }\end{array}$ \\
\hline $\begin{array}{c}\text { 17 Januari } \\
\text { - April } \\
2019\end{array}$ & $\begin{array}{c}7 \\
\text { Peserta }\end{array}$ & APHP & $\begin{array}{c}\text { SMKN } 4 \\
\text { Gorut } \\
\text { SMKN } 2 \\
\text { Limboto }\end{array}$ \\
\hline $\begin{array}{c}\text { 20 Januari } \\
\text { - April } \\
2020\end{array}$ & $\begin{array}{c}7 \\
\text { Peserta }\end{array}$ & APHP & $\begin{array}{c}\text { SMKN } 4 \\
\text { Gorut } \\
\text { SMKN } 2 \\
\text { Limboto }\end{array}$ \\
\hline
\end{tabular}

Dari beberapa Angkatan di atas berdasarkan hasil penelitian yang ada terdapat beberapa minat yang rendah dalam berwirausaha yaitu di tahun 2019 karena kebanyakan masalah pada permodalan dan tidak ada dukungan dari keluarga, akan tetapi berbeda 
dengan tahun 2020 lebih banyak minat peserta untuk berwirausaha karena di tahun 2020 lebih meningkatnya penjualan online dan sebagian dari siswa lebih berminat dengan melakukan penjualan online.

Adanya minat berwirausaha akan menjadikan seseorang lebih giat mencari dan memanfaakan peluang usaha dengan mengoptimalkan potensi yang dimiliki. Minat tidak dibawa sejak lahir tetapi tumbuh dan berkembang sesuai dengan faktor-faktor yangmempengaruhinya.

Faktor-faktor tersebut antara lain faktor dari dalam (internal), faktor sosial (external), dan faktor emosi, jadi faktor-faktor itulah yang nantinya akan memperkuat atau memperlemah minat.

\section{Tinjauan Pustaka}

\section{Efektivitas Kerja}

Menurut Budiani (2007;21)

Efektivitas Kerja adalah kesesuaian antara output dengan tujuan yang di tetapkan. Efektivitas adalah suatu keadaan yang terjadi karena di kehendaki. Pada era globalisasi saat ini perkembangan dan kemajuan di berbagai bidang selalu mengedepankan efektivitas kerja para pegawai yang dapat menggerakan sekaligus menjalankan roda organisasi. Dewasa ini efektivitas kerja pegawai dapat di lihat pada berbagai kegiatan penggalangan pelatihan ketatausahaan pada lembaga pemerintah maupun swasta. Terciptanya efektiviatas kerja yang baik di harapkan mampu unuk dapat menjamin percepatan, kelancaran, pelayanan terhadap masyarakat secara baik dan tepat.
Keterpaduan tugas dan fungsi penyelenggaraan pemerintah maupun swasta dalam meningkatkan efektivitas kerja dalam organisasi. Efektivitas merupakan penilaian hasil pengukuran dalam arti tercapainya tujuan yang telah di tetapkan sebelumnya. Efektivitas perlu di perhatikan sebab mempunyaiefek yang besar terhadap kepentingan orang banyak. Efektivitas berarti bahwa tujuan yang telah di rencanakan sebelumnya dapat tercapai atau dengan kata lain sasaran tercapai karena dengan adanya proses kegiatan. Efektivitas juga dapat di pandang agar pelaksanaan adminitrasi lebih mencapai hasil seperti apa yang di rencanakn, mencapai sasaran tujuan yang ingin di capai dan lebih berhasil guna.

Menurut Winandi ( 2010;75) menyatakan, keefektifan dapat di lakukan dengan menspesifikai sarana untuk seluruh organisasi, dan individu serta kelompok- kelompok pada organisasi perlu di koordinasikan.

Efektivitas menunjukkan kemampuan suatu perusahaan dalam mencapai sasaran yang telah di tetapkan secara tepat. Pencapaian sasaran yang telah di tetapkan berdasarkan ukuran maupun standar yang berlaku mencerminkan suatu perusahaan tersebut telah memperhatikan efektivitas operasionalnya.

\section{Kewirausahaan}

Kewirausahaan adalah semangat, sikap, perilaku dan kemampuan seseorang dalam menangani usaha atau kegiatan yang mengarah kepada upaya mencari, menciptakan, menerapkan cara kerja, 
teknologi dan produk baru dengan meningkatkan efisiensi dalam rangka memberikan pelayanan yang lebih baik dan atau memperoleh keuntungan yang lebih besar ( Inpres 1995;4 ). Menurut Fuadi dalam Ardi Subagyo (2008:9), minat berwirausaha adalah keinginan, ketertarikan, serta kesediaan untuk bekerja keras, berusaha secara maksimal dalam memenuhi kebutuhan hidupnya tanpa merasa takut dengan resiko yang akan terjadi, serta berkemauan keras untuk belajar dari kegagalan ( Daryanto 2012;5).

Secara garis besar, kewirausahaan meliputi 3 komponen utama dari wirausaha yaitu: 1.Kepribadian, 2.Motivasi dan kemampuan, 3.Fasilitas danpertumbuhan.

Berwirausaha adalah kegiatan untuk melakukan suatu usaha berdasarkan ide-ide kreatif dan inovatif dengan karakteristik kepribadiannya berani menghadapi tantangan, siap mental, mempunyai kepercayaan diri, berorientasi ke masa depan serta mempunyai keterampilan untuk memenuhi kebutuhan $(2001 ; 6)$.

Menurut Suryaman (2006:22) minat berwirausaha adalah kemampuan untuk memberanikan diri dalam memenuhi kebutuhan hidup serta memecahkan permasalahan hidup, memajukan usaha atau menciptakan usaha baru dengan kekuatan yang ada pada diri sendiri.

Minat berwirausaha adalah keinginan, ketertarikan, serta kesediaan untuk bekerja keras atau berkemauan keras untuk berusaha memenuhi kebutuhan hidupnya tanpa merasa takut dengan resiko yang akan terjadi, serta senantiasa belajar dari kegagalan.

Efektifitas dalam meningkatkan minat berwirausaha pada siswa. Dengan kegiatan Praktek Kerja Lapangan ini, siswa akan memperoleh nilai penampilan kerja yang merupakan nilai mengenai sikap, dan perilaku siswa selama PKL. Nilai-nilai ini merupakan ukuran dari pengalaman PKL yang di lakukan oleh siswa tersebut. Sifat, watak dan ciri-ciri yang melekat pada seseorang yang berkaitan dengan wirausaha dapat menjadi indicator minat kewirausahaan seseorang. Oleh karena itu melalui pelaksanaan PKL di harapkan siswa memiliki karakter berwirausaha. Karakter wirausaha ini menjadi indicator minat berwirausaha siswa.

Indicator tinggi dan rendahnya minat berwirausaha peserta PKL di ukur dari seluruh pelatihan keterampilan, dimana proses pengukuran di lakukan sebelum siswa mengikuti pelatihan maupun setelah siswa menempuh pelatihan. Hasil penilaian menerangkan bahwa setelah mengikuti pelatihan keterampilan minat berwirausaha siswa pelatihan keterampilan mengalami peningkatan dari semula sebelum mengikuti pelatihan keterampilan. (Nurjanah,2016).

\section{Metode Penelitian \\ Jenis Penelitian}

Jenis penelitian yang dilakukan dalam penelitian kualitatif. Uraian deskriptif menjadi unsur-unsur utama dalam penelitian ini karena yang terbatas pada usaha mengungkapkan 
suatu masalah dan keadaan sebagaimana adanya (Suharsimi 2000;16).

Penelitian kualitatif sebagai prosedur penelitian yang menghasilkan data deskriptif berupa kata tertulis atau lisan dari orang-orang dalam perilaku yang dapat diamati.

Metode yang digunakan dalam penelitian ini bertujuan untuk mendapatkan data-data berdasarkan keadaan yang ada, hasil wawancara langsung dengan informan dan dari dokumen-dokumen yang ada (Lexi J. Molong 2005;56).

Penelitian ini menggunakan pendekatan sosial penjualan karena terkait langsung dengan gejala-gejala kewirausahaan, untuk mengetahui minat siswa berwirausaha dan faktor yang mempengaruhi minat siswa berwirausaha.

Dalam penelitian kualitatif ini peneliti bertindak sebagai instrumen penelitian yang dapat berhubungan langsung informan dan objek lain. Kehadiran peneliti sebagai utama dalam penelitian ini akan dapat mengetahui kondisi atau faktor yang mempengaruhi minat siswa-siswa PKL dalam berwirausaha. Yang terjadi pada lokasi penelitian atau suatu kenyataan yang terjadi dilapangan sehingga data yang dikumpulkan memang benarbenar akurat dan sesuai dengan kebutuhan dalam penelitian.

Penelitian ini di lakukan di Pia Putra Kusuma yang beralamat Jl. Thayeb Moh. Gobel, Kel. Molosifat U, Kec Sipatana, Perum Balkin Blok A No 1. Dengan rentang waktu penelitian selama kurang lebih 3 bulan terhitung dari bulan Februari sampai bulan April.

Sumber data yang di gunakan adalah data yang bersumber dari Pimpinan Pia Putra Kusuma Yakni Ibu Lilik Sriani dan siswa dari SMK N 2 LIMBOTO Yakni Fadila Akase, Siti F Abudi, Melfiani Ibrahim, Novita Pilomonu, Salma Kawongi, Serlin Hulilungo, Irma Mohune. yang terdiri dari data primer dan data sekunder. Data primer yaitu suatu data yang di peroleh secara langsung oleh peneliti dari Informan sebagai objek penelitan, yaitu Pimpinan Pia Putra Kusuma dengan siswa Prakterk Kerja Lapangan ( PKL ) SMK N 2 Limboto.

Data sekunder yaitu data yang di peroleh secara tidak langsung kepada informan dengan melalui perantara yaitu segala sumber yang ada relevansinya dengan objek yang teliti yakni dokumentasi Dalam pengecekan tentang kebenaran hasil penelitian, maka peneliti mengambil beberapa informan di antaranya :

Tabel 2 Narasumber

\begin{tabular}{|r|c|c|}
\hline No & Nama & Jabatan \\
\hline 1. & Lilik Sriani & $\begin{array}{c}\text { Pimpinan } \\
\text { Perusahaan } \\
\text { Pia Putra } \\
\text { Kusuma }\end{array}$ \\
\hline 2. & Tahir Nusi & $\begin{array}{c}\text { Sekretaris } \\
\text { Perusahaan } \\
\text { Pia Putra } \\
\text { Kusuma }\end{array}$ \\
\hline 3. & Bendahara & $\begin{array}{c}\text { Fadlan P. } \\
\text { Wungguli }\end{array}$ \\
\hline 4. & Putra & $\begin{array}{c}\text { Bagian } \\
\text { Pemasaran }\end{array}$ \\
\hline 5. & Risna Mile & Karyawan \\
\hline
\end{tabular}




\begin{tabular}{|r|c|c|}
\hline 6. & Linda Biludi & Karyawan \\
\hline 7. & Santi Thalib & Karyawan \\
\hline 8. & Werda Nusi & Karyawan \\
\hline 9. & Nurmalasari Nusi & Karyawan \\
\hline 10. & Wulan & Karyawan \\
\hline 11. & Anton & Karyawan \\
\hline 12. & Fadila Akase & $\begin{array}{c}\text { Peserta } \\
\text { magang }\end{array}$ \\
\hline 13. & Siti Abudi & $\begin{array}{c}\text { Peserta } \\
\text { magang }\end{array}$ \\
\hline 14. & Melfian Ibrahim & $\begin{array}{c}\text { Peserta } \\
\text { magang }\end{array}$ \\
\hline 15. & Novita pilomonu & $\begin{array}{c}\text { Peserta } \\
\text { magang }\end{array}$ \\
\hline 16. & Salma kawongi & $\begin{array}{c}\text { Peserta } \\
\text { magang }\end{array}$ \\
\hline 17. & Serlin hulilungo & $\begin{array}{c}\text { Peserta } \\
\text { magang }\end{array}$ \\
\hline 18. & Irma mohune & $\begin{array}{c}\text { Peserta } \\
\text { magang }\end{array}$ \\
\hline
\end{tabular}

\section{Metode dan Teknik Pengumpulan Data}

Dalam penelitian ini mengumpulkan data dilakukan dengan menggunakan teknik observasi, wawancara, dan dokumentasi.

\section{Teknik Analisa Data}

Teknik analisa data dalam penelitian ini berupa cerita rinci para informan sesuai dengan ungkapan atau pandangan mereka apa adanya kemudian juga berupa pembahasan yakni diskusi antara data temuan dengan teori-teori yang digunakan. Data-data dikumpulkan dan dianalisis setiap meninggalkan lapangan. Menurut Miles and Huberman (Sugiyono,2007) aktivitas dalam analisa data yaitu data reduction, data display, dan conclusion drawing/verification.
Dimana proses pengumpulan data, reduksi data, dan verifikasi/kesimpulan merupakan proses siklus yang berlangsung secara simultan dan saling berinteraksi satu sama lain.

Secara runtut, teknik analisa data dilakukan melalui tahapan 1)Reduksi data dilakukan melalui proses pemilihan, pemusatan perhatian pada penyederhanaan, pengabstrakan dan transformasi data yang muncul dari catatan-catatan tertulis di lapangan. Reduksi data merupakan suatu bentuk analisa untuk menajamkan, menggolongkan, mengarahkan, membuang yang tidak perlu, dan mengorganisasikan data sehingga kesimpulannya dapat ditarik dan diverifikasi. 2)Penyajian data. Dalam kegiatan ini dilakukan penyajian sekumpulan informasi yang memberikan kemungkinan adanya penarikan kesimpulan dan pengambilan tindakan. Penyajian tersebut dilakukan dalam bentuk tabel dan bagan. 3)Penarikan kesimpulan atau verifikasi. Penarikan kesimpulan adalah upaya mencari arti data yang tercatat mengenai pola-pola penjelasan konfigurasi-konfigurasi yang mungkin, alur sebab akibat, dan preposisi. Kegiatan reduksi data, penyajian data, dan penarikan kesimpulan atau verifikasi merupakan kegiatan yang menjalin antara sebelum, selama dan sesudah pengumpulan data dalam bentuk yang sejajar. 


\section{Hasil Penelitian}

Efektifitas pelaksanaan praktek kerja lapangan (PKL) dalam meningkatkan minat berwirausaha bagi siswa

Dalam hasil penelitian ini tujuannya untuk mengetahui Efektivitas Kerja dari peserta magang siswa SMK dalam meningkatkan Minat Berwirausaha siswa di perusahaan Pia Putra Kusuma. Penyajian data pada penelitian kali ini tidak terlepas dari fokus permasalahan mengenai efektifitas pelaksanaan praktek kerja lapangan (PKL) dalam meningkatkan minat berwirausaha bagi siswa di LKP Pia Putra Kusuma. Dimana peserta magang diharapkan dapat mengimplementasikan ilmu berwirausaha yang sudah di dapatkan disekolah dan mempelajari kembali halhal yang tidak ada di sekolah melalui bimbingan langsung dari pemilik usaha.Dengan praktek kerja inilah yang membuat siswa lebih kompeten dan tertarik untuk bisa berwirausaha. Dimana ia akan belajar bagaimana persoalan penyediaan modal, bahan baku, tenaga kerja, produksi, dan sampai pada tahap pendistribusian. Dalam siklus inilah ia akan menjadi seseorang yang mahir dalam menganalisis untuk bagaimana perusahaan mendapatkan laba/keuntungan yang sesuai.

\section{Praktek Kerja Lapangan (PKL) atau Magang}

Magang merupakan salah satu tahapan di antara dunia kerja dan dunia sekolah.Magang merupakan suatu proses yang dijalani oleh seseorang untuk memahami ruang lingkup pekerjaan, cara kerja, hingga sistem kerja, dengan cara melakukan praktik kerja secara langsung di dalam bidang kerja yang terkait.Lebih lanjut lagi dijelaskan di dalam Peraturan UndangUndang No. 13 tahun 2003 tentang Ketenagakerjaan Pasal 21 hingga Pasal 30 bahwa magang didefinisikan sebagai salah satu bagian dari sistem pelatihan kerja yang diselenggarakan secara terpadu antara lembaga pelatihan (institusi pendidikan) dengan perusahaan secara langsung, dibawah pengawasan instruktur.Nah dari sini sebenarnya kemudian ada beberapa sekolah (SMK) yang mewajibkan para siswanya untuk magang sebelum lulus, artinya magang menjadi salah satu syarat kelulusan bagi para siswa SMK. Seiring dengan perkembangannya istilah magang diganti menjadi praktek kerja lapangan (PKL). PKL adalah kegiatan pendidikan, pelatihan dan pembelajaran yang dilaksanakan didunia usaha atau dunia industri yang relevan dengan dengan kompetensi (kemampuan) siswa sesuai bidangnya. Dan juga sudah mendapatkan bekal dari pembimbing di sekolah untuk memiliki ilmu-ilmu dasar yang akan diterapkan dalam dunia usaha atau dunia Industri.

Dalam wawancara yang dilakukan oleh peneliti terhadap informan yaitu karyawan perusahaan Pia Putra Kusuma (LB) terkait dengan hal-hal yang berkaitan dengan peserta magang beliau menyatakan bahwa: "cukup membantu atau saling membantu dan juga perusahaan sangat terbantu oleh peserta magang dalam hal pekerjaan. kinerja siswa saat magang sangat baik dan mengikuti aturan pada perusahaan yang 
sudah di tetapkan. perilaku mereka baik dan mereka pun berusahan mengikuti aturan perusahaan. strategi yang saya lakukandalam mengarahkan peserta magang tentang cara produksi Pia yakni dengan menjadi instruktur dan memberitahukan tata cara dan tehnik pembuatan pia yang benar. Kendala-kendala yang sering dihadapi yakni mereka yang terkadang masih lamban untuk memahami.dalam hal pemasaran mereka cukup bagus karena peserta magang ratarata adalah pengguna social media seperti fb jadi mereka tidak malu dalam memasarkan barang. untuk minat berwirausaha saya perhatikan ada yang benar-benar suka dan juga ada yang tidak berminat. untuk motivasi saya sering menciptakan suasana yang senang dan di menganggap peserta $\mathrm{pkl}$ adalah teman lama atau atau karyawan yang sudah lama bekerja di perusahaan Pia Putra Kusuma sehingga peserta merasakan senang".

Pada prinsipnya keberadaan peserta magang dianggap sangat membantu segala bentuk kegiatan yang ada di perusahaan Pia Putra Kusuma.Mulai dari kegiatan produksi sampai pada tahap pemasaran. Hal ini menunjukan bahwa kinerja peserta magang di anggap cukup baik di perusahaan Pia Putra Kusuma.

\section{Industri Usaha}

Industri merupakan bagian dari proses produksi. Bahan-bahan industri diambil secara langsung maupun tidak langsung, kemudian diolah, sehingga menghasilkan barang yang bernilai lebih bagi masyarakat.Sejalan dengan hal tersebut "FA" selaku peserta magang di perusahaan Pia Putra Kusuma menyampaikan juga beberapa hal terkait dengan di dunia industri yakni: "pendapat saya tentang dunia industri khususnya pada perusahaan pia putra kusuma bagi saya pribadi dapat membantu untuk menambah skill karena pada dasarnya kami siswa smk lebih di prioritaskan untuk bisa langsung terjun ke dunia kerja seperti halnya pada perusahaan pia putra kusuma. selama kami magang di perusahaan ini kami tidak merasakan hambatan karena karyawan-karyawan disini sangat ramah dan sangat baik dalam mengarahkan proses produksi. di sekolah kami hanya mendapatkan pengetahuan teori tentang wirausaha sedangkan di dunia industri saya mendapatkan pengalaman dan menerapkan langsung. setelah saya merasakan magang ini saya mnjadi tertarik untuk berwirausaha karena secara pribadi saya memiliki niat untuk berwirausaha karena saya melihat dan merasakan secara langsung keuntungan yang di dapat ketika kita berwirausaha. ajaran yang di berikan oleh pimpinan dan karyawan tidak berbeda jauh dengan ajaran yang di berikan oleh guru-guru disekolah. Hanya saja disini kami langsung dapat melakukan praktek secara langsung dan terakadang mendapat beberapa Kendala yang biasanya tidak ada di teori yang di ajarkan disekolah".

Berdasarkan uraian di atas, maka peneliti dapat menarik kesimpulan bahwa keberadaan peserta magang dilokasi industry di anggap sangat membantu proses kegiatan operasional, mulai dari tahapan produksi sampai pada tahapan pemasaran. Hubungan antar keduanya terjalin dengan cukup baik dimana perusahaan sangat terbantu dengan keberadaan peserta magang olehnya mereka menyadari perlu memberikan 
apresiasi melalui pembimbingan yang secara terstruktur dan kompeten untuk kemajuan dan pengembangan kualitas diri peserta magang.dan untuk peserta magang mereka diberikan kesempatan untuk terjun langsung dan ikut serta dalam industry. yang membuat mindset peserta magang tentang berwirausaha menjadi lebih baik lagi dan semakin menyukai dunia wirausaha itu sendiri. Minat berwirausaha peserta magang di LKP Pia Putra Kusuma

Berwirausaha adalah suatu kegiatan usaha yang melibatkan kemampuan untuk melihat kesempatan-kesempatan usaha yang kemudian mengorganisisr, mengatur, mengambil resiko, dan mengembangkan usaha yang diciptakan tersebut guna meraih keuntungan. Menurut uraian tentang minat dan wirausaha di atas, minat berwirausaha adalah kecenderungan hati dalam diri subyek untuk tertarik menciptakan suatu usaha yang kemudian mengorganisir, mengatur, menanggung resiko dan mengembangkan usaha yang diciptakannya tersebut (Narendra C. Bhandari, 2007).

Sejalan dengan hal tersebut, hal yang sama juga terjadi di perusahaan Pia putra kusuma dimana pimpinan diharapkan untuk bisa mengorganisir segala kegiatan yang berkaitan dengan usahanya.Tanpa terkecuali peran pimpinan dalam mengorganisir peserta magang SMK yang bekerjasama dalam kegiatan operasional industri usaha LKP Pia Putra Kusuma.adapun wawancara peneliti dengan pimpinan perusahaan Pia Putra Kusuma terkait dengan minat berwirausaha siswa peserta magang di LKP Pia Putra Kusuma yakni: "Siswa siswi yang magang di tempat saya berbeda-beda ada yang bersungguh-sungguh dalam belajar berwirausaha, ada yang hanya ikut ikutan ada juga yang malas-malasan. Ya, mungkin karena kurang berminat dalam berwirausaha mungkin juga hanya karena paksaan dari orang tua tapi kebanyakan siswa yang magang di tempat saya banyak yang berkeinginan untuk berwirausaha, yang tidak berminat itu mungkin hanya 1 atau 2 orang saja. Dalam mengajrkan siswa pkl memang sangat banya kendalanya salah satunya awalnya dalam pembuatan produksi tidak semua siswa paham dan berminat membuat produksi, dalam pemasaran kebanyakan siswa tidak berkeinginan turun langsung ke lapangan untuk melakukan pemasaran"

Melalui hasil wawancara di atas, maka peneliti dapat menarik kesimpulan bahwa minat berwirausaha siswa peserta magang yang ada di LKP Pia Putra Kusuma cukup beragam. Tidak semua dari mereka memiliki minat dalam berwirausaha.Tetapi hal tersebut tidak untuk semua peserta magang, ada juga beberapa dari mereka yang memang berkeinginan untuk bisa berwirausaha setelah menamatkan jenjang pendidikan yang ada di sekolah.

\section{Pembahasan}

Efektifitas Pelaksanaan Praktek Kerja Lapangan (PKL) Dalam Meningkatkan Minat Berwirausaha Bagi Siswa Di LKP Pia Putra Kusuma

Berdasarkan pemaparan pada deskripsi hasil penelitian, efektifitas pelaksanaan praktek kerja lapangan 
dalam meningkatkan minat berwirausaha siswa di LKP Pia Putra Kusuma cukup baik dimana hampir semua siswa mampu membantu segala kegiatan operasional usaha melalui bimbingan dan usaha dari karyawan maupun pimpinan. Tetapi memang bukan tidak mungkin jika tidak ada kendala pada siswa atau pembimbingan di lokasi industry usaha. Praktek kerja lapangan merupakan model mengajar dalam bentuk kerja lapangan,dimana Model ini menyelenggarakan pendidikan profesional yang memadukan secara sistematis dan sinkronisasi antara pendidikan di sekolah dan penguasaan keahlian atau keterampilan di dunia usaha untuk mencapai tingkat yang cukup profesional.

LKP Pia Putra Kusuma hampir setiap tahun dilirik oleh sekolah menengah kejuruan (SMK)sebagai tempat praktek kerja lapangan untuk siswa. Hal ini karena LKP Pia Putra Kusuma Dianggap sebagai tempat yang mampu melahirkan individu yang kompeten dalam berwirausaha. Pelaksanaan praktek kerja lapangan di LKP Pia Putra Kusuma diharapkan dapat di manfaatkan dengan baik oleh siswa, sehingga ilmu yang merekadapatkanbisa berguna untuk ke depannya dan dapat mengetahui kondisi dunia usaha yang sebenarnya. Dengan begitu, keberadaan praktek kerja lapangan ini diharapkan dapat meningkatkan kualitas lulusan SMK yang handal dan profesional dan mampu bersaing di dunia kerja.

Praktek kerja lapangan selain melahirkan lulusan yang handal dan professional dibidangnya disisi lain tujuan dari praktek kerja lapangan untuk bisa menumbuhkan minat siswa dalam berwirausaha. Siswa SMK harus memiliki minat ke arah wirausaha, yaitu minat yang tinggi terhadap pembukaan suatu usaha. Minat adalah hal penting dalam melakukan usaha, adanya minat membuat seseorang lebih bersemangat dalam menjalani usaha. Minat tidak muncul begitu saja tetapi tumbuh dan berkembang sesuai dengan faktorfaktor yang mempengaruhinya. Jadi minat dalam berwirausaha merupakan hal yang dapat dipelajari dan seiring berjalannya waktu atau dengan pengalaman minat berwirausaha seseorang bisa tumbuh.

Mengapa minat berwirausaha menjadi sangat penting, tidak lain alasannya agar lulusan yang tidak berkesempatan dan berkeinginan melanjutkan studi dapat menciptakan peluang untuk berwirausaha secara mandiri dan dapat membuka lapangan pekerjaan untuk orang banyak. Oleh karena itu seluruh Pihak yang menjadi bagian dalam LKP Pia Putra Kusuma menjadi pihak yang berperan penting di dalam peningkatan minat berwirausaha dari para peserta magang. Hal ini juga terlihat dari berbagi upaya yang dilakukan oleh seluruh karyawan membimbing satu persatu peserta magang dalam setiap kegiatan yang ada di sana. Dan hasilnya cukup baik dimana hampir semua peserta magang sangat bersungguh-sungguh dalam melaksanakan perannya berwirausaha yang baik di dunia usaha. Hanya saja ha ini tidak terjadi pada satu atau dua 
orang peserta magang. yang masih belum bersungguh-sungguh.

Faktor-faktor yang mempengaruhi minat berwirausaha peserta magang di LKP Pia Putra Kusuma

Minat berwirausaha adalah kemampuan untuk memberanikan diri dalam memenuhi kebutuhan hidup serta memecahkan permasalahan hidup, memajukan usaha atau menciptakan usaha baru dengan kekuatan yang ada pada diri sendiri. Dari pengertian di atas dapat disimpulkan minat berwirausaha adalah keinginan, ketertarikan, serta kesediaan untuk bekerja keras atau berkemauan keras untuk berusaha memenuhi kebutuhan hidup nyata merasa takut denga resiko yang akan terjadi, serta senantiasa belajar dari kegagalan. Factor yang mempengaruhi minat berwirausaha antara lain Faktor Internal dan Faktor Eksternal.

\section{Faktor Internal}

Factor internal merupakan factor yang berasal dari dir isendiri tanpa di pengaruhi oleh keadaan diluar diri. Faktor Internal antara lain : 1) Mengembangkan kemampuan berbakat dalam bidang usaha/bisnis atau minat berwirausaha 2) Keberhasilan dari diri memiliki pengaruh positif dan signifikan terhadap minat berwirausaha. 3) Berkeinginan untuk menjadi pribadi yang mandiri dalam hal berwirausaha. 4) Untuk mengembangkan skill atau pengalaman kerja dalam dunia wirausaha.

\section{Faktor Eksternal}

Faktor eksternal merupakan factor yang sifatnya dari luar atau yang mendapat persetujuan dan dapat di terima oleh lingkungan. Factor Eksternal lantara lain : 1) Minat berwirausaha yang pengaruhnya paling dekat yakni orang tua karena orang tua selalu mendukung dan member kebebasan dalam hal berwirausaha. 2) Pendidikan merupakan salah satu faktor dari luar untuk meningktakan minat atau cara untuk berwirausaha. 3) Lingkungan merupakan factor yang mempungaruhi untuk berwirausaha, dengan adanya faktor lingkungan tersebut maka dorongan untuk memulai usaha/bisnis akan semakin meningkat. 4) Memotivasi diri dalam melakukan sesuatu. Tanpa adanya motivasi dari diri sendiri maka untuk memulai suatu usaha tidak akan sesuai dengan keinginan sendiri, hal yang sedang dilakukan.

\section{Penutup}

Kesimpulan

Melalui hasil penelitian peneliti menarik kesimpulan bahwa Efektifitas kerja peserta magang siswa SMK dalam meningkatkan minat berwirausaha pada perusahaan PIA PUTRA KUSUMA GORONTALO, Efektifitas Pelaksanaan Praktek Kerja Lapangan (PKL) Dalam Meningkatkan Minat Berwirausaha Bagi Siswa Di LKP Pia Putra Kusuma sudah efektif. Berdasarkan pemaparan pada deskripsi penelitian ini, efektifitas pelaksanaan praktek kerja lapangan dalam meningkatkan minat berwirausaha siswa di LKP Pia Putra Kusuma cukup baik dimana hampir semua siswa mampu membantu segala kegiatan operasional usaha melalui bimbingan dan usaha dari karyawan maupun 
pimpinan. Faktor-faktor yang mempengaruhi minat siswa berwirausaha bagi peserta magang adalah faktor internal dan faktor eksternal.

Saran

Sejalan dengan kesimpulan dalam penelitian ini maka peneliti memberikan saran sebagai berikut:

1. Kepada pihak LKP Pia Putra Kusuma untuk lebih memberikan motivasi kepada peserta magang yang tujuan untuk meningkatkan minat mereka di dalam berwirausaha

2. Penelitian ini bisa dijadikan referensi untuk bahan penelitian selanjutnya yang memiliki topik bahasan serupa mengenai Efektifitas kerja peserta magang siswa SMK dalam meningkatkan minat berwirausaha pada perusahaan Pia Putra Kusuma Gorontalo dengan mengangkat indikator tentang me Efektifitas kerja peserta magang siswa SMK dalam meningkatkan minat berwirausaha pada studi kasus lainnya.

\section{Daftar Pustaka}

Albertus Yudi Yuniarto, 2004. Minat Mahasiswa Peserta Mata Kuliah Kewirausahaan di Jurusan Manajemen FE USD untuk Berwirausaha. JurnalAntisipasiVol.8,No.1. Pojok BEI.Yogyakarta: Fakultas Ekonomi USD.

Alma, Boukari. 2001. Kewirausahaan. Bandung:Alfabeta.1:4
Arikunto Suharsimi, 2000 Prosedur Penelitian Suatu Pendekatan Praktis, (Jakarta:Bumi Aksara).h.16

Boukari Alma, 2001. Kewirausahaan, Bandung:Alfabeta.:6 Inpres No. 4 tahun1995

Budiani, N. W 2007. Jurnal Ekonomidan Sosial

Chaplin, J.P.. 2002. KamusPsikologi. Jakarta :(PT. Raja GarfindoPersada.) hal.78

Daryanto. 2012. Pendidikan kewirausahaan. Yogyakarta :Gava Media.:5

Daryanto. 2012. Yogyakarta:Gava Media.:6

Daryanto. $2005 \quad$ Pendidikan kewirausahaan. Yogyakarta :Gava Media.:20

Elisabeth Hurlock,.1994. Perkembangan Anak.Jakarta :(Erlangga.) hal. 58

Gie, (2000, hal 29). AdministrasiPerkantoran Modern

Hendrik Tanjung dan Abrista Devi, 2013. Metodologi Peneliti Ekonomi Islam, Edisi 1(JAKARTA Gramasta Publising),h.91

Kau Sopyan.A.P. 2009.Metodologi Penelitian Hukum Islam (cet 1: : Sultan Amai Press IAIN Gorontalo, Desember).h.200-201

Lexi J. Molong, 2005. Metodologi Penelitian Kualitatif (Bandung Remaja Rosdakarya),h. 56

Maman Suryaman. 2006. Minat Berwirausaha pada Mahasiswa Pendidikan Teknik Elektro Fakultas Teknik Universitas Negeri Semarang. Sugiyono, 2013. Metode Penelitian Manajemen: Alpabeta).h.235 Ibid h.228 
Subanar, H. 2001. Manajemen Usaha Kecil.Yogyakarta: BPFE UGM.:14

Winkel. 1997. Bimbingan Konseling pada Institusi Pendidikan.(Jakarta: Erlangga.) hal 520

Wibowo, Agus. 2011. Pendidikan kewirausahaan. Yogyakarta :PustakaPelajar.:34 6263

Zimmemer, Thomas W. and Norman M. Scarborough.2002

Entrepreneurship and Small Business Management.:25

Zimmemer\&Scarborough, $2002: 37$ 